
\title{
-
}

(940

\section{Topical Application of Propolis Enhances Cutaneous Wound Healing by Promoting TGF-Beta/Smad-Mediated Collagen Production in a Streptozotocin-Induced Type I Diabetic Mouse Model}

\author{
Wael N. Hozzein a, Gamal Badrc Ahmad A. Al Ghamdi Ayat Sayed \\ Noori S. Al-Wailif Olivier Garraudg,h \\ aBioproducts Research Chair, Department of Zoology, College of Science, King Saud University, \\ Riyadh, Saudi Arabia; ${ }^{b}$ Botany Department, Faculty of Science, Beni-Suef University, Beni-Suef, Egypt; \\ 'Laboratory of Immunology and Molecular Physiology, Zoology Department, Faculty of Science, Assiut \\ University, Assiut, Egypt; ${ }^{d}$ Chair of Engineer Abdullah Baqshan for Bee Research, College of Food and \\ Agriculture Sciences, King Saud University, Riyadh, Saudi Arabia; eDepartment of Biochemistry, Faculty \\ of Medicine, Assiut University, Assiut, Egypt; ${ }^{\mathrm{f} A l-W a i l i ' s ~ F o u n d a t i o n ~ f o r ~ S c i e n c e, ~ N e w ~ Y o r k, ~ U S A ; ~} 9$ Institut \\ National de la Transfusion Sanguine, Paris, France; 'Université de Lyon, Saint-Etienne, France
}

Key Words

Cytokines • Diabetes mellitus • Inflammation • Propolis • Wound healing

\begin{abstract}
Background/Aims: Impaired wound healing is considered to be one of the most serious complications associated with diabetes as it significantly increases the susceptibility of patients to infection. Propolis is a natural bee product used extensively in foods and beverages that has significant benefits to human health. In particular, propolis has antioxidant, anti-inflammatory and analgesic effects that could be useful for improving wound healing. In this study, we investigated the effects of topical application of propolis on the healing and closure of diabetic wounds in a streptozotocin (STZ)-induced type I diabetic mouse model. Methods: Sixty male mice were distributed equally into 3 experimental groups: group 1, non-diabetic control mice; group 2, diabetic mice; and group 3, diabetic mice treated daily with a topical application of propolis. Results: We found that diabetic mice exhibited delayed wound closure characterized by a significant decrease in the levels of TGF- $\beta 1$ and a prolonged elevation of the levels of inflammatory cytokines (IL-1 $\beta$, IL- 6 and TNF- $\alpha$ ) and MMP9 in wound tissues compared with control non-diabetic mice. Moreover, the wound tissues of diabetic mice showed a marked reduction in the phosphorylation of Smad2 and Smad3 as well as a marked reduction in collagen production. Interestingly, compared with untreated diabetic mice, topical application of propolis significantly enhanced the closure of diabetic wounds and decreased the levels of IL-1 $\beta$, IL- 6 , TNF- $\alpha$ and MMP9 to near normal levels. Most importantly, compared with untreated diabetic mice, the treatment of diabetic mice with propolis significantly enhanced

Dr. Gamal Badr, Associate Professor of Immunology

Zoology Department, Faculty of Science, Assiut University, 71516 Assiut, (Egypt) Tel. +201110900710, Fax +20882080642,

E-Mail badr73@yahoo.com or gamal.badr@aun.edu.eg
\end{abstract}




\section{Cellular Physiology Cell Physiol Biochem 2015;37:940-954 \\ \begin{tabular}{ll|l} 
and Biochemistry & $\begin{array}{l}\text { DOI: 10.1159/000430221 } \\
\text { Published online: September 18, } 2015\end{array}$ & $\begin{array}{l}\text { (c) } 2015 \mathrm{~S} \text {. Karger AG, Basel } \\
\text { www.karger.com/cpb }\end{array}$ \\
\cline { 2 - 3 } Hozzein et al: Propolis Enhances the Healing of Diabetic Wounds
\end{tabular}}

the production of collagen via the TGF- $\beta 1 / \mathrm{Smad} 2,3$ signaling axis in wounded tissues. Conclusion: Our findings reveal the molecular mechanisms underlying the improved healing and closure of diabetic wounds following topical propolis application.

Copyright (C) 2015 S. Karger AG, Basel

\section{Introduction}

Diabetic wounds represent an added burden for diabetic patients and health care providers worldwide as they have low healing potential and residual ulceration due to associated neuropathy and vasculopathy [1]. Wound healing consists of overlapping but coordinated processes, including homeostasis, inflammation, granulation tissue formation and tissue remodeling [2]. An array of cytokines, growth factors, immune and inflammatory mediators, as well as their associated signaling cascades, are involved in tissue regeneration and wound closure [3]. In diabetes, both the cellular and extracellular milieus are abnormal, showing prolonged inflammatory and immune responses, impaired growth factor production, decreased angiogenesis and the production of atypical extracellular components and remodeling matrix metalloproteinases (MMPs) $[4,5]$.

The pro-inflammatory cytokines IL-1 $\beta$, IL- 6 and TNF- $\alpha$ are primarily released by immune cells early during the wound healing process (inflammatory stage) and act as effectors for keratinocytes and fibroblasts to stimulate tissue deposition and epithelialization [6,7]. Persistent inflammation has been directly linked to delayed healing and wound chronicity [5]. Indeed, high levels of these cytokines are found in diabetic ulcers and have been associated with scarring events, which is the end result of fibroblast apoptosis and extracellular matrix (ECM) degradation [8].

The proper tensile strength and biomechanical properties of wounds are dependent on the biochemical composition of the wound during the late remodeling stages of the healing process, and they are governed primarily by the type of collagen deposited in the extracellular matrix [9] and the balance between MMPs and their tissue inhibitors [10]. Type I collagen, a major extracellular matrix component, not only confers strength and integrity to the tissue matrix but also plays an important role in homeostasis and epithelialization during the later stages of wound healing [11]. Decreased collagen deposition has been reported as a mechanism of delayed wound healing, as indicated by low hydroxyproline levels in the presence of normal collagenase activity in both diabetic humans [12] and experimental diabetes models [13]. Delayed wound healing is also affected by increased levels of collagen type III relative to collagen type I in the wounds of diabetic mice compared with non-diabetic controls [14]. The presence of MMPs is required early during wound healing to stimulate the mobilization of keratinocytes and activate the precursors of various inflammatory mediators and growth factors [10]. Prolonged and excessive expression of MMP9 during the later stages of wound healing are detrimental, as they lead to ECM decomposition and a reduction in the tensile strength of the wound, as is observed in diabetic wounds $[15,16]$.

Upon binding of the TGF- $\beta$ ligand to receptors with serine/threonine kinase activity, Smad 2 and Smad3 become phosphorylated, causing them to bind to Smad4 and translocate into the nucleus, where they activate or repress the expression of TGF- $\beta$ target genes [17]. TGF- $\beta$ is an important regulator of wound healing, and it is released by platelets very early during the wound healing process. In particular, TGF- $\beta$ is responsible for the chemotaxis of inflammatory and immune cells to the wound site [18]. TGF- $\beta$ also stimulates the deposition of extracellular matrix and the formation of granulation tissue [19]. Moreover, TGF- $\beta$ is important for the final steps of tissue remodeling during wound healing by mediating the replacement of collagen type III with collagen type I [20]. TGF- $\beta$ also supports wound epithelialization by stimulating keratinocyte proliferation and modulating integrin expression to induce a more migratory phenotype [21]. Indeed, defective TGF- $\beta$ signaling contributes to delayed wound healing in diabetes $[22,23]$.

The treatment of diabetic wounds is a challenge in clinical practice, and the development of more effective treatment strategies is required. One promising pharmacological candidate 


\section{Cellular Physiology Cell Physiol Biochem 2015;37:940-954 \begin{tabular}{c|l}
\hline DOI: 10.1159/000430221 & (C) 2015 S. Karger AG, Basel
\end{tabular} and Biochemistry Published online: September 18, $2015 \quad$ www.karger.com/cpb \\ Hozzein et al.: Propolis Enhances the Healing of Diabetic Wounds}

is propolis, which has been safely used for centuries and is relatively inexpensive. Propolis is a natural product found in plant materials and is processed by worker bees by mixing the material with salivary enzymes and wax [24]. The well-established anti-inflammatory [25], antioxidant [26] and antibacterial [27] properties of propolis make it an attractive candidate for the treatment of diabetic wounds in animals [28, 29] and humans [30,31]. However, the mechanisms through which propolis induces wound healing, particularly in the context of diabetes, are still poorly understood. Therefore, the current study was conducted to elucidate the biochemical basis and signaling pathways through which the topical application of propolis enhances diabetic wound healing.

\section{Materials and Methods}

\section{Propolis preparation}

Honey Spring propolis (batch number 4A80) was collected from Saudi Arabia by Eng. Abdullah Baqshan, Chair for Bee Research at the College of Food and Agriculture Sciences, King Saud University. Collection of the propolis and determination of its contents were identifies in our laboratory using highspeed counter current chromatography and off-line atmospheric pressure chemical ionization massspectrometry injection as previously described [32]. Briefly, preparations of propolis extract consisted of three phases including drying, extracting, and evaporating. The drying process began by washing the sample, cutting it into small pieces, and putting them in the oven with a temperature of $40-60^{\circ} \mathrm{C}$. Before the extraction process, samples were dried and then crushed by a blender. 200 grams of dry samples were weighed and put in $1 \mathrm{~L}$ Erlenmeyer glass, soaked with ethanol to the volume of $1 \mathrm{~L}$ (20\%). Sample in ethanol was stirred for \pm 30 minutes and allowed to stand overnight to settle. Then, solution containing the active substance was filtered with filter paper. Soaking process was repeated three times and the last stage was evaporation. Extraction solvent was inserted into $1 \mathrm{~L}$ evaporation flask. Then, water bath was filled with water up to a full circuit and then installed according to an equipment protocol and set to a temperature of $90^{\circ} \mathrm{C}$. Ethanol was allowed to drip in the flask $( \pm 1.5-2$ hours/flask containing $\pm 900 \mathrm{ml})$. Extraction results obtained roughly one tenth of dried natural materials (20 grams extract/200 gram's sample). A final solution equivalent to $400 \mathrm{mg} / \mathrm{ml}$ was prepared by dissolving this extract ( 20 grams) in $50 \mathrm{ml}$ of $70 \%$ ethanol and this final solution was stored in hermetically-sealed brown-glass bottles at room temperature. Previous studies have shown that the prepared propolis extract using this method is stable for 6 months, maintaining its antimicrobial and antioxidant activities over this period [33]. According to numerous data in our laboratory, using different animal models, a daily dose of ethanolic soluble derivative of propolis (5-20 mg topically applied to wounded area) does not show any toxic effects and subsequently this dose is categorized safe. We therefore, used an optimal dose of ethanolic soluble derivative of propolis $(25 \mu \mathrm{l}$ equivalent to $10 \mathrm{mg}$ ) daily applied for the treatment of normal and diabetic mice.

\section{Chemicals}

Streptozotocin (STZ) was obtained from Sigma Chemicals Co. (St. Louis, MO, USA). STZ was dissolved in cold $0.01 \mathrm{M}$ citrate buffer (pH 4.50), which was freshly prepared (within $5 \mathrm{~min}$ ) as needed.

\section{Animals and diabetes induction}

A total of 60 sexually mature 12-week-old male BALB/c mice weighing 25-30 g each were obtained from the Central Animal House of the Faculty of Pharmacy at King Saud University. All animal procedures were conducted in accordance with the standards set forth in the Guidelines for the Care and Use of Experimental Animals by the Committee for the Purpose of Control and Supervision of Experiments on Animals (CPCSEA) and the National Institutes of Health (NIH). The Animal Ethics Committee of the Zoology Department, College of Science, King Saud University approved the protocol used in this study according to the Helsinki Principles. All animals were acclimated to metal cages in a well-ventilated room for 2 weeks prior to experimentation. The animals were maintained under standard laboratory conditions $\left(23^{\circ} \mathrm{C}, 60\right.$ $70 \%$ relative humidity and a 12-h light/dark cycle), fed a standard diet of commercial pellets and given water ad libitum. All mice were fasted for $20 \mathrm{~h}$ prior to diabetes induction. The mice $(n=40)$ were rendered diabetic by intraperitoneal (i.p.) injection of STZ (60 mg/kg body weight in $0.01 \mathrm{M}$ citrate buffer $\mathrm{pH} 4.5$ ) 


\section{Cellular Physiology Cell Physiol Biochem 2015;37:940-954 \begin{tabular}{ll|l} 
and Biochemistry & $\begin{array}{l}\text { DOI: 10.1159/000430221 } \\
\text { Published online: September 18, } 2015\end{array}$ & $\begin{array}{l}\text { C } 2015 \text { S. Karger AG, Basel } \\
\text { www.karger.com/cpb }\end{array}$ \\
\hline
\end{tabular} \\ Hozzein et al.: Propolis Enhances the Healing of Diabetic Wounds}

daily for 5 consecutive days [34, 35]; mice in the control group $(n=20)$ were injected with vehicle alone (0.01 M citrate buffer, $\mathrm{pH} 4.5$ ). Mice were considered diabetic if glycemia was higher than $220 \mathrm{mg} / \mathrm{dl}$. The animals were housed for 2 weeks prior to wound formation and propolis treatment.

\section{Excisional wound preparation and macroscopic examination}

Two weeks post-diabetes induction, the mice were wounded as previously described [34]. Briefly, the mice were anesthetized with a single i.p. injection of ketamine ( $80 \mathrm{mg} / \mathrm{kg}$ body weight) and xylazine (10 $\mathrm{mg} / \mathrm{kg}$ body weight). The hair on the back of each mouse was shaved, and the back was cleaned with $70 \%$ ethanol. Two wounds (8 $\mathrm{mm}$ in diameter, 3-4 mm apart) were made on the back of each mouse by excising the skin and underlying panniculus carnosus. The animals were then divided into three experimental groups: group 1, control non-diabetic mice topically treated with $25 \mu \mathrm{l} 70 \%$ ethanol (vehicle)/wounded area/day for 15 days $(n=20)$; group 2, diabetic mice topically treated with $25 \mu$ l vehicle/wounded area/day for 15 days $(n=20)$; and group 3, diabetic mice topically treated with $25 \mu$ l of ethanolic soluble derivative of propolis ( $25 \mu$ l equivalent to $10 \mathrm{mg}$ ) / wounded area/day for 15 days $(\mathrm{n}=20)$. The optimal dose of propolis was determined in our laboratory on the basis of the $\mathrm{LD}_{50}$ value and several previously established parameters. Propolis was painted onto the entire wound surface with a sterile cotton bud. Skin biopsy specimens were obtained from the animals at 3, 6, 9, 12, and 15 days post-wounding. For each time point, a skin sample - which included the scab, the complete epithelial and dermal compartments of the wound margins, the granulation tissue, and portions of the adjacent muscle and subcutaneous fat tissue - was excised from each individual wound. As a control, a similar sample of skin was collected from the backs of non-wounded wild-type mice. Each wound site was digitally photographed at the indicated time intervals to document the wound area. Changes in the wound area are expressed as a percentage of the initial wound area. At the indicated time intervals, the tissue of two wounds from ten animals ( $n=20$ wounds) was collected for RNA, western blot and ELISA analyses.

\section{Measurement of hydroxyproline content in the wound sites}

At the indicated time intervals after the injury, skin wound sites were removed using a sterile disposable biopsy punch and were dried for $24 \mathrm{~h}$ at $120^{\circ} \mathrm{C}$, the levels of hydroxyproline, a major constituent of collagen in skin wound sites, was measured to quantify collagen accumulation at the wound site, as previously described [36]. Hydroxyproline content was calculated by comparison to standards and is expressed as the amount $(\mu \mathrm{g})$ per wounded tissue weight.

\section{Blood analysis}

Blood glucose levels were determined using an AccuTrend sensor (Roche Biochemicals; Mannheim, Germany). Luminex (Biotrend; Düsseldorf, Germany) was used to analyze serum insulin levels, according to the manufacturer's instructions.

\section{Biochemical analysis of wounded tissues}

Measuring cytokine levels. A 2.0-mm punch biopsy taken from the wound site was harvested and frozen in liquid nitrogen. Specimens were homogenized in cytoplasmic lysis buffer containing protease inhibitors (Roche Diagnostics), disrupted using Fast Prep (Q-Biogene; Solon, OH, USA), and centrifuged at $5000 \times \mathrm{g}$ for $10 \mathrm{~min}$. The protein concentration in each lysate was determined using the bicinchoninic acid (BCA) protein assay kit (Pierce; Rockford, IL, USA). The supernatants were then assayed to determine IL-1 $\beta$, IL-6, TNF- $\alpha$, TGF- $\beta 1$, MMP2 and MMP9 levels using a commercial ELISA kit (R\&D Systems; France), according to the manufacturer's instructions. The results are expressed as target molecule (picograms) per total protein (milligrams) for each sample.

\section{Western blot analysis}

The skin and wound tissue biopsies were homogenized in lysis buffer (1\% Triton X-100, $137 \mathrm{mM} \mathrm{NaCl,}$ $10 \%$ glycerol, $1 \mathrm{mM}$ dithiothreitol, $10 \mathrm{mM} \mathrm{NaF}, 2 \mathrm{mM} \mathrm{Na}_{3} \mathrm{VaO}_{4}, 5 \mathrm{mM}$ ethylenediaminetetra-acetic acid, 1 $\mathrm{mM}$ phenylmethylsulfonylfluoride, $5 \mathrm{ng} / \mathrm{ml}$ aprotinin, $5 \mathrm{ng} / \mathrm{ml}$ leupeptin and $20 \mathrm{mM}$ Tris/ $\mathrm{HCl}, \mathrm{pH} \mathrm{8.0}$ ), and the lysates were prepared as previously described [37]. Fifty micrograms of total protein from the skin lysates was analyzed using SDS-polyacrylamide gel electrophoresis (SDS-PAGE) and western blot analysis. Antibodies (Abs) directed against anti-collagen type 1 antibody (1:5000) phospho-Smad2 (pSmad2) 


\section{Cellular Physiology Cell Physiol Biochem 2015;37:940-954 \\ \begin{tabular}{l|l}
\hline DOI: 10.1159/000430221 & (c) 2015 S. Karger AG, Basel
\end{tabular} \\ and Biochemistry Published online: September 18, $2015 \quad$ www.karger.com/cpb \\ Hozzein et al.: Propolis Enhances the Healing of Diabetic Wounds}

(1:1000), pSmad3 (1:1000), total Smad2 (1:2000), total Smad3 (1:2000) and $\beta$-actin (1:4000) (all from Abcam, Paris, France) were used in combination with horseradish peroxidase-conjugated secondary Abs, and the proteins were visualized using an enhanced chemiluminescence (ECL, Supersignal Westpico chemiluminescent substrate; Perbio, Bezons, France) detection system. The ECL signal was detected on Hyperfilm ECL. To quantify the band intensities, the films were scanned, saved as TIFF files, and then analyzed using the NIH Image J software program.

\section{Statistical analysis}

The data were tested for normality (using an Anderson-Darling test) and variance homogeneity prior to further statistical analysis. The data were normally distributed and are expressed as the mean \pm SEM (standard error of the mean). Significant differences between groups were analyzed using one-way analysis of variance (for more than two groups) followed by Tukey's post-test using SPSS software version 17. Data are expressed as the mean \pm SEM. Differences were considered statistically significant at ${ }^{*} \mathrm{P}<0.05$ for diabetic vs. control; ${ }^{+} \mathrm{P}<0.05$ for diabetic + propolis vs. control; or ${ }^{\#} \mathrm{P}<0.05$ for diabetic + propolis vs. diabetic.

\section{Results}

\section{Propolis enhances wound closure in diabetic mice}

We evaluated macroscopic changes at the skin-excision wound sites in control mice, diabetic mice and diabetic mice treated topically with the ethanolic soluble derivative of propolis. Pictures were taken on day 0 , immediately following injury. The wound sites exhibited a similar morphology in all 3 experimental groups on day 3 post-injury. The wounds in the control and diabetic mice treated with propolis showed nearly similar degree of closure at 15 days post-injury. By contrast, the diabetic mice exhibited delayed wound closure. A representative result is shown (Fig. 1A). The accumulated data showing the change in the percentage of wound closure at each time point (relative to the original wound area) from 10 mice per group are shown (Fig. 1B). These results showed that wound closure and healing were accelerated in diabetic mice treated topically with the ethanolic soluble derivative of propolis compared with diabetic mice treated with vehicle alone. We also measured the blood glucose and insulin levels in the 3 groups of mice before and throughout the indicated time points post-wounding. Accumulated data from 10 animals from each group revealed that the diabetic mice exhibited significant elevation in the glucose levels and significant decrease in the insulin levels compared to the control non diabetic mice (Table 1). However, when the diabetic mice were treated with the ethanolic soluble derivative of propolis the blood glucose levels were not significantly decreased and the insulin levels were not significantly increased compared to the diabetic mice treated with vehicle (Table 1).

Topical application of propolis to diabetic wounds restores the levels of wound-tissue proinflammatory cytokines, TGF- $\beta 1$ and MMP9

ELISAs were used to measure the levels of pro-inflammatory cytokines, TGF- $\beta 1$ and MMP9, which play important roles in wound healing, in the excisional wound tissues collected from the 3 groups of mice on days 3, 6, 9, 12 and 15 post-wounding. Day 0 samples were collected one hour prior to wound formation (non-wounded skin tissue). The accumulated data from 10 individual mice from each group revealed elevated levels of pro-inflammatory cytokines (IL-1 $\beta$, IL-6, and TNF- $\alpha$ ) and MMP9 in diabetic mice compared with controls, as shown in Fig. 2. In particular, the diabetic mice exhibited elevated levels of the proinflammatory cytokines IL-1 $\beta$ (Fig. 2A), IL-6 (Fig. 2B) and TNF- $\alpha$ (Fig. 2C), as well as MMP9 (Fig. 2D), compared with control non-diabetic animals. Interestingly, the diabetic mice that were treated topically with the ethanolic soluble derivative of propolis showed a partial but significant restoration of wild-type expression for IL-1 $\beta$ (Fig. 2A), IL-6 (Fig. 2B), TNF- $\alpha$ (Fig. 2C), and MMP9 (Fig. 2D) compared with vehicle-treated diabetic animals. Nevertheless, in contrast to the levels of pro-inflammatory cytokines and MMP9, diabetic mice exhibited a 


\section{Cellular Physiology Cell Physiol Biochem 2015;37:940-954 \begin{tabular}{l|l|l}
\hline DOI: 10.1159/000430221 & O 2015 S. Karger AG, Basel
\end{tabular} and Biochemistry Published online: September 18, 2015 www.karger.com/cpb

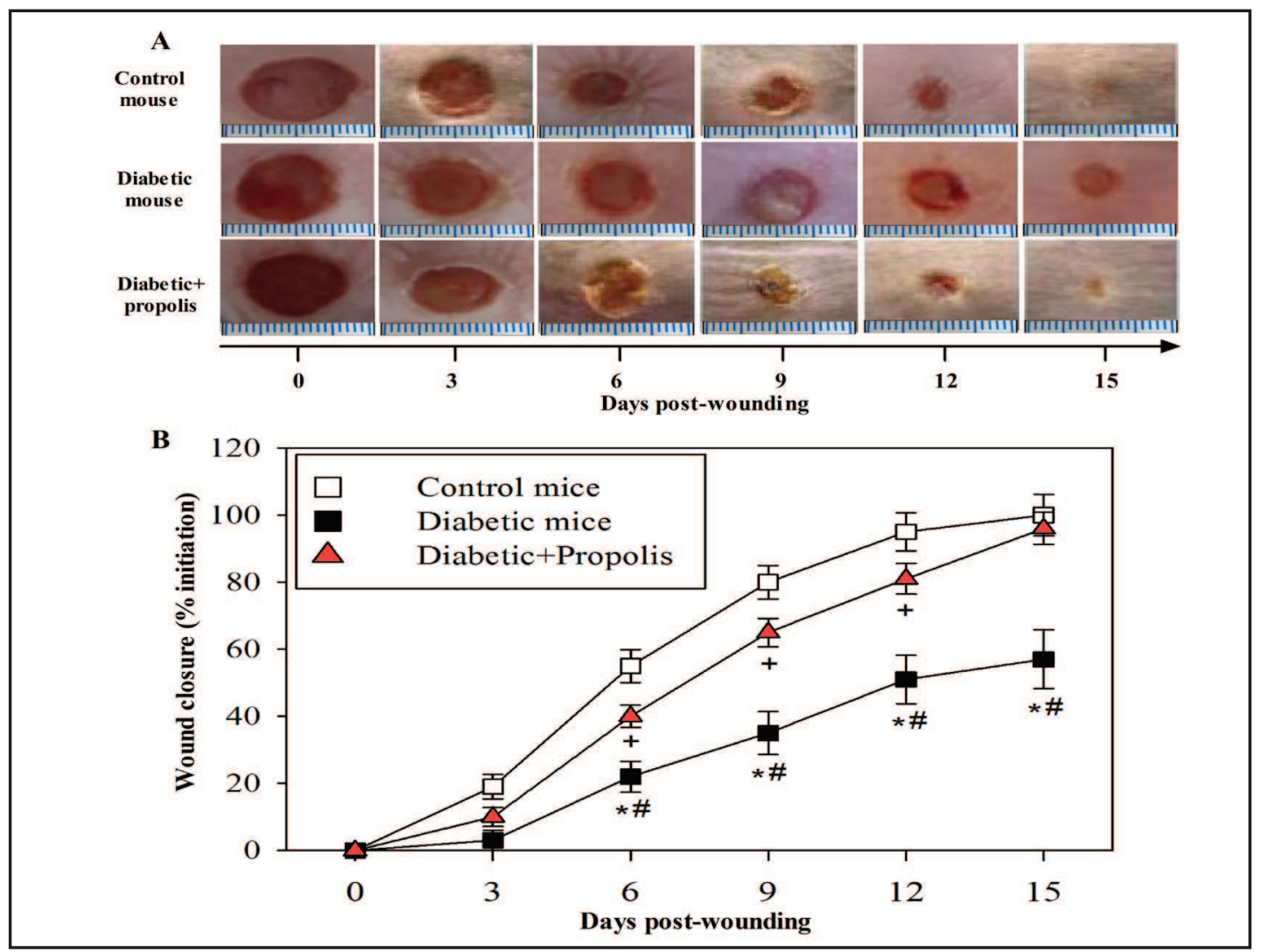

Fig. 1. Macroscopic changes in skin excisional wounds during wound closure. (A) The wound sites were photographed at the indicated intervals. The pictures at day 0 were taken immediately after injury. (B) Representative data from 10 individual mice per group indicating changes in the percentage of wound closure. The data are presented as mean \pm SEM values. ${ }^{*} \mathrm{P}<0.05$, diabetic vs. control; ${ }^{+} \mathrm{P}<0.05$, diabetic + propolis vs. control; " $\mathrm{P}<0.05$, diabetic + propolis vs. diabetic.

Table 1. Blood glucose and insulin levels in the three groups of mice from the onset of diabetic induction until the end of the experiments

\begin{tabular}{lccc}
\hline & \multicolumn{3}{c}{ Blood glucose level (mg/dL) } \\
\hline & Control mice & Diabetic mice & Diabetic + propolis \\
Onset of diabetic induction & $120 \pm 11$ & $260 \pm 15.8^{*}$ & $244 \pm 16.4+$ \\
Two weeks post-diabetes induction & $127 \pm 12$ & $344 \pm 18.2^{*}$ & $315 \pm 18.4+$ \\
0 day post-wounding & $101 \pm 10$ & $360 \pm 16^{*}$ & $311 \pm 17.2+$ \\
3 days post-wounding & $90 \pm 9.8$ & $368 \pm 19^{*}$ & $339 \pm 18+$ \\
6 days post-wounding & $131 \pm 13.8$ & $370 \pm 22^{*}$ & $353 \pm 21+$ \\
9 days post-wounding & $128 \pm 11.6$ & $345 \pm 21^{*}$ & $326 \pm 19+$ \\
12 days post-wounding & $162 \pm 12.4$ & $392 \pm 21.6^{*}$ & $362 \pm 20.8+$ \\
15 days post-wounding & $139 \pm 14.4$ & $386 \pm 19.4 *$ & $359 \pm 21+$ \\
& & & \\
& & $B l o o d$ & insulin level (ng/ml) \\
& Control mice & Diabetic mice & Diabetic + propolis \\
Onset of diabetic induction & $5.6 \pm 0.5$ & $3.1 \pm 0.29 *$ & $3.7 \pm 0.28+$ \\
Two weeks post-diabetes induction & $5.7 \pm 0.36$ & $2.2 \pm 0.22^{*}$ & $2.6 \pm 0.26+$ \\
0 day post-wounding & $4.9 \pm 0.32$ & $1.6 \pm 0.18^{*}$ & $1.7 \pm 0.21+$ \\
3 days post-wounding & $5.1 \pm 0.4$ & $1.8 \pm 0.19^{*}$ & $1.9 \pm 0.18+$ \\
6 days post-wounding & $5.2 \pm 0.4$ & $1.9 \pm 0.22 *$ & $1.95 \pm 0.19+$ \\
9 days post-wounding & $4.9 \pm 0.33$ & $2.1 \pm 0.2 *$ & $2.3 \pm 0.2+$ \\
12 days post-wounding & $5.4 \pm 0.45$ & $2.1 \pm 0.16^{*}$ & $2.2 \pm 0.25+$ \\
15 days post-wounding & $4.98 \pm 0.35$ & $2.05 \pm 0.18 *$ & $2.4 \pm 0.16+$ \\
& & & \\
* $<0.05$ Diabetic vs control. & & & \\
+0.05 Diabetic + propolis vs control. & & & \\
\hline
\end{tabular}




\section{\begin{tabular}{cl|l} 
Cellular Physiology & Cell Physiol Biochem 2015;37:940-954 \\
\cline { 2 - 3 } DOI: 10.1159/000430221 & \\
and Biochemistry Published online: September 18, 2015 & $\begin{array}{l}\text { O 2015 S. Karger AG, Basel } \\
\text { www.karger.com/cpb }\end{array}$
\end{tabular} \\ Hozzein et al.: Propolis Enhances the Healing of Diabetic Wounds}

Fig. 2. Changes in the levels of pro-inflammatory cytokines and MMP9 during wound healing. The levels of pro-inflammatory cytokines (IL-1 $\beta$, IL-6, TNF- $\alpha$ and TGF- $\beta$ ) and MMP9 were measured in the 3 groups of mice using ELISA prior to wound formation (Day 0) and on the indicated days post-wounding. The results are presented as cytokine levels (pg) per ml of wounded tissue lysate and expressed as mean \pm SEM values $(n=10)$. $\mathrm{P}<0.05$, diabetic vs. control; ${ }^{+} \mathrm{P}<0.05$, diabetic + propolis vs. control (ANOVA with Tukey's post-test).

marked and significant reduction in the levels of TGF- $\beta 1$ compared with control non-diabetic mice (Fig. 2E). Most importantly, the diabetic mice that were treated topically with the ethanolic soluble derivative of propolis showed a partial but significant restoration of TGF- $\beta 1$ levels compared with vehicle-treated diabetic animals.

Propolis-treated diabetic mice exhibit clear changes in TGF- $\beta$ 1-mediated phosphorylation of Smad2 and Smad3 in the wound tissue

TGF- $\beta 1$ mediates activation of the transcription factors Smad2 and Smad3, leading to the production of collagen, which in turn acts as a regulator of the wound healing processes. Therefore, the expression and activation of Smad2 and Smad3 were investigated in the excisional wound tissues from the three groups of mice at 6, 9 and 12 days post-wounding. A representative immunoblot showing one of the five experiments is shown (Fig. 3A \& B). In particular, immunoblots

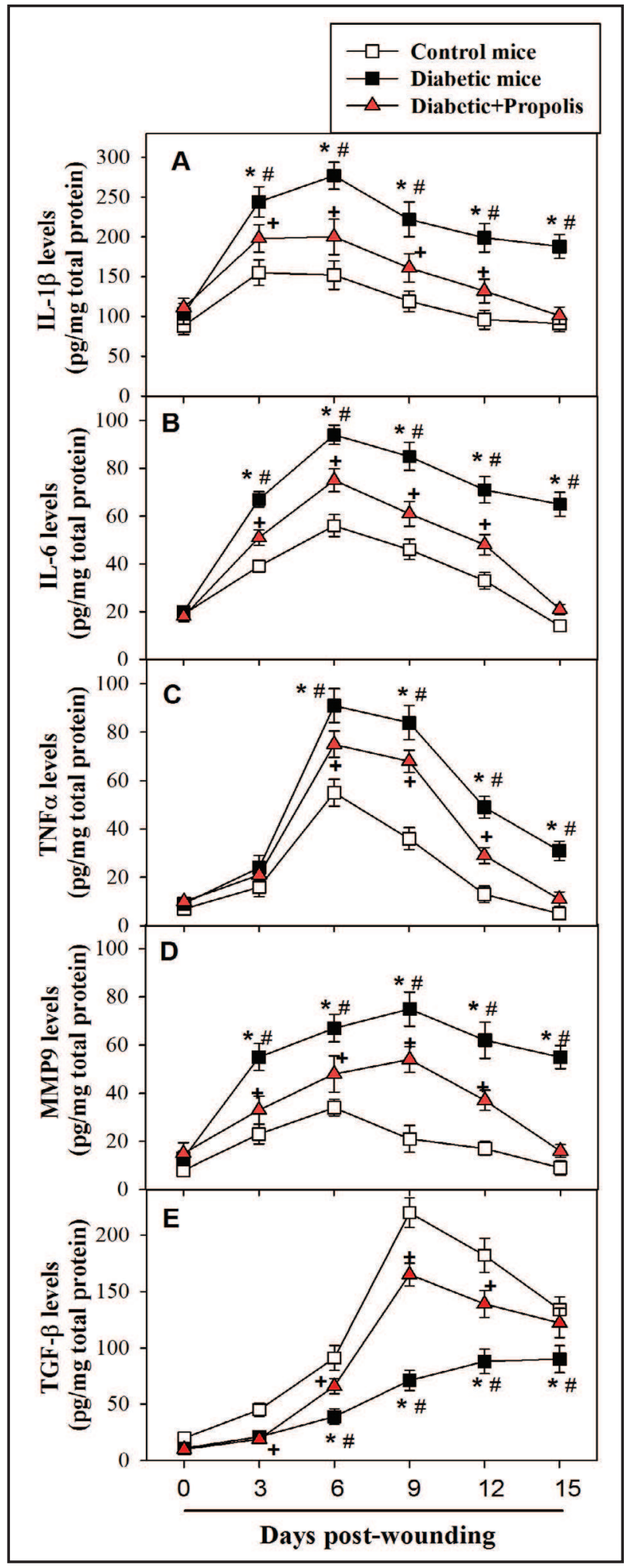

of phosphorylated Smad2, total Smad2 and total $\beta$-actin (loading control) (Fig. 3A), phosphorylated Smad3, total Smad3 and total $\beta$-actin (loading control) (Fig. 3B) are shown in control non-diabetic mouse (CM), vehicle-treated diabetic mouse (DM) and diabetic mouse treated with propolis $(\mathrm{DM}+\mathrm{P})$ in wounded tissues at 6, 9 and 12 days post-wounding. We found that the phosphorylation of Smad2 and Smad3 were markedly reduced in vehicle- 


\section{Cellular Physiology Cell Physiol Biochem 2015;37:940-954 \begin{tabular}{l|l|l}
\hline DOI: 10.1159/000430221 & O 2015 S. Karger AG, Basel
\end{tabular} and Biochemistry Published online: September 18, 2015 www.karger.com/cpb

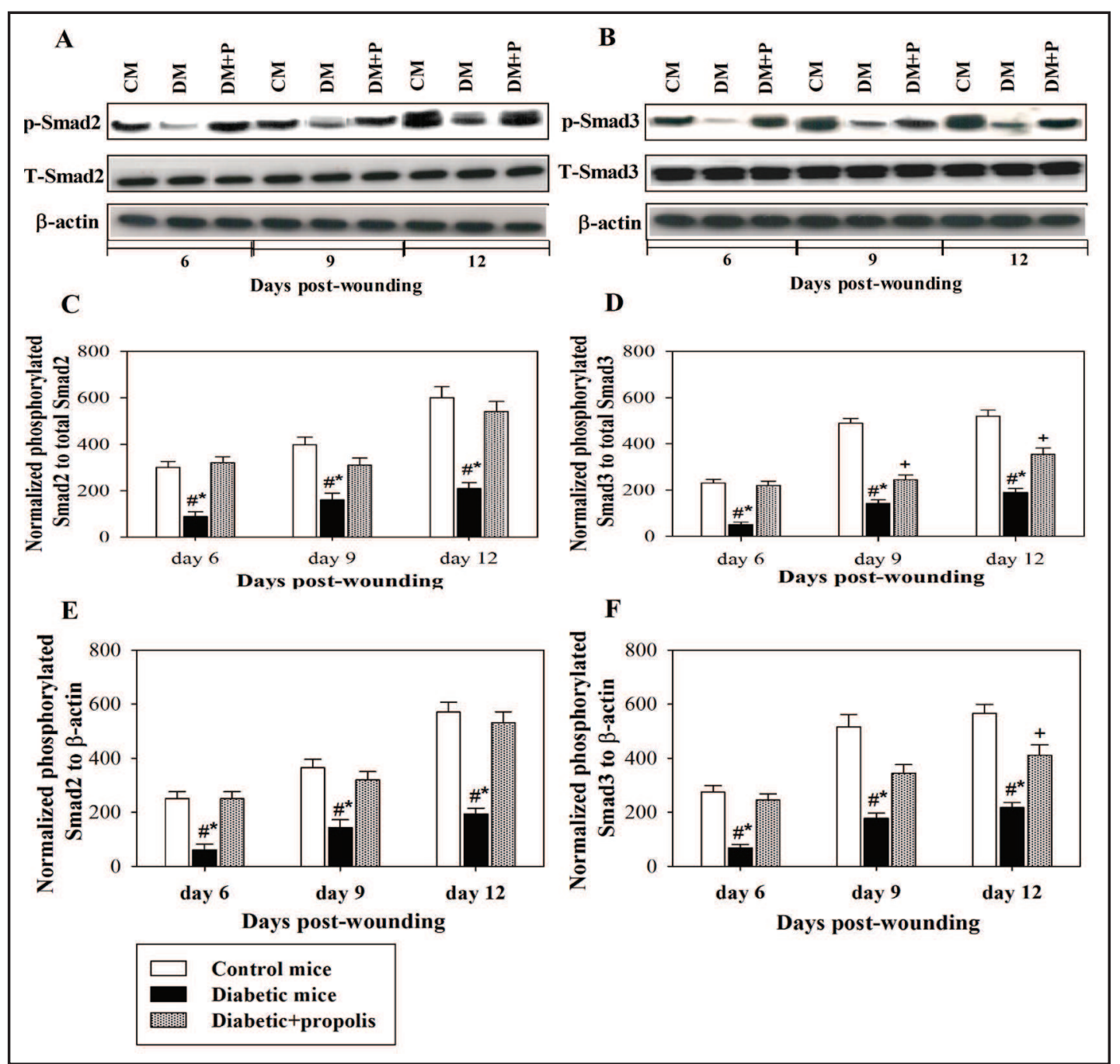

Fig. 3. Topical application of propolis affects the phosphorylation of Smad2 and Smad3 in wounded tissues. Immunoblots showing one representative experiment is shown for phosphorylated Smad2 and total Smad2 (A), phosphorylated Smad3 and total Smad3 (B) in control non-diabetic mouse (CM), diabetic mouse (DM) and diabetic mouse treated topically with propolis (DM+P). Accumulated data from five independent experiments are shown for normalized Smad2 (C) and Smad3 (D) phosphorylation in control non-diabetic (open bars), diabetic (closed black bars) and diabetic animals treated topically with propolis (gray dotted bars) in wounded skin samples (at 6, 9 and 12 days post-wounding). Values represent the mean $\pm \mathrm{SEM}$. ${ }^{*} \mathrm{P}<0.05$, diabetic vs. control; ${ }^{+} \mathrm{P}<0.05$, diabetic + WP vs. control; ${ }^{*} \mathrm{P}<0.05$, diabetic + WP vs. diabetic (ANOVA with Tukey's post-test).

treated diabetic mice, as the immunoblots showed very low intensity bands over the entire wound healing process compared with control non-diabetic mice. By contrast, the propolis-treated diabetic mice displayed enhanced phosphorylation of Smad2 and Smad3, which peaked at 9 and 12 days post-injury, similar to the levels observed in the control nondiabetic mice. Nevertheless, treatment of diabetic mice with propolis had no effect on the expression of Smad2 and Smad3. Accumulated data from five individual mice per group are shown for the normalized phosphorylation of Smad2 to the total relevant Smad2 (Fig. 3C) and normalized phosphorylation of Smad3 to the total relevant Smad3 (Fig. 3D). We found that vehicle-treated diabetic mice (closed black bars) exhibited a significant reduction in the normalized Smad2 and Smad3 phosphorylation from days 6 to 12 post-wounding compared with control (open bars) and propolis-treated diabetic mice (gray dotted bars). 


\section{Cellular Physiology \\ Cell Physiol Biochem 2015;37:940-954 and Biochemistry

Fig. 4. Propolis enhances collagen production in diabetic wounds. (A) Hydroxyproline content, an index of collagen accumulation at wound sites, was determined. Values represent the mean \pm SEM. (B) Western blot analysis was performed to measure the expression of collagen type I as a protein and $\beta$-actin in wounded skin samples (at 6, 9 and 12 days post-wounding). (C) Accumulated data from five independent experiments are shown for normalized collagen type I expression in control non-diabetic (open bars), diabetic (closed black bars) and diabetic animals treated topically with propolis (gray dotted bars) in wounded skin samples (at 6, 9 and 12 days post-wounding). Values represent the mean \pm SEM. ${ }^{*} \mathrm{P}<0.05$, diabetic vs. control; ${ }^{+} \mathrm{P}<0.05$, diabetic + WP vs. control; " $\mathrm{P}<0.05$, diabetic + WP vs. diabetic (ANOVA with Tukey's post-test).

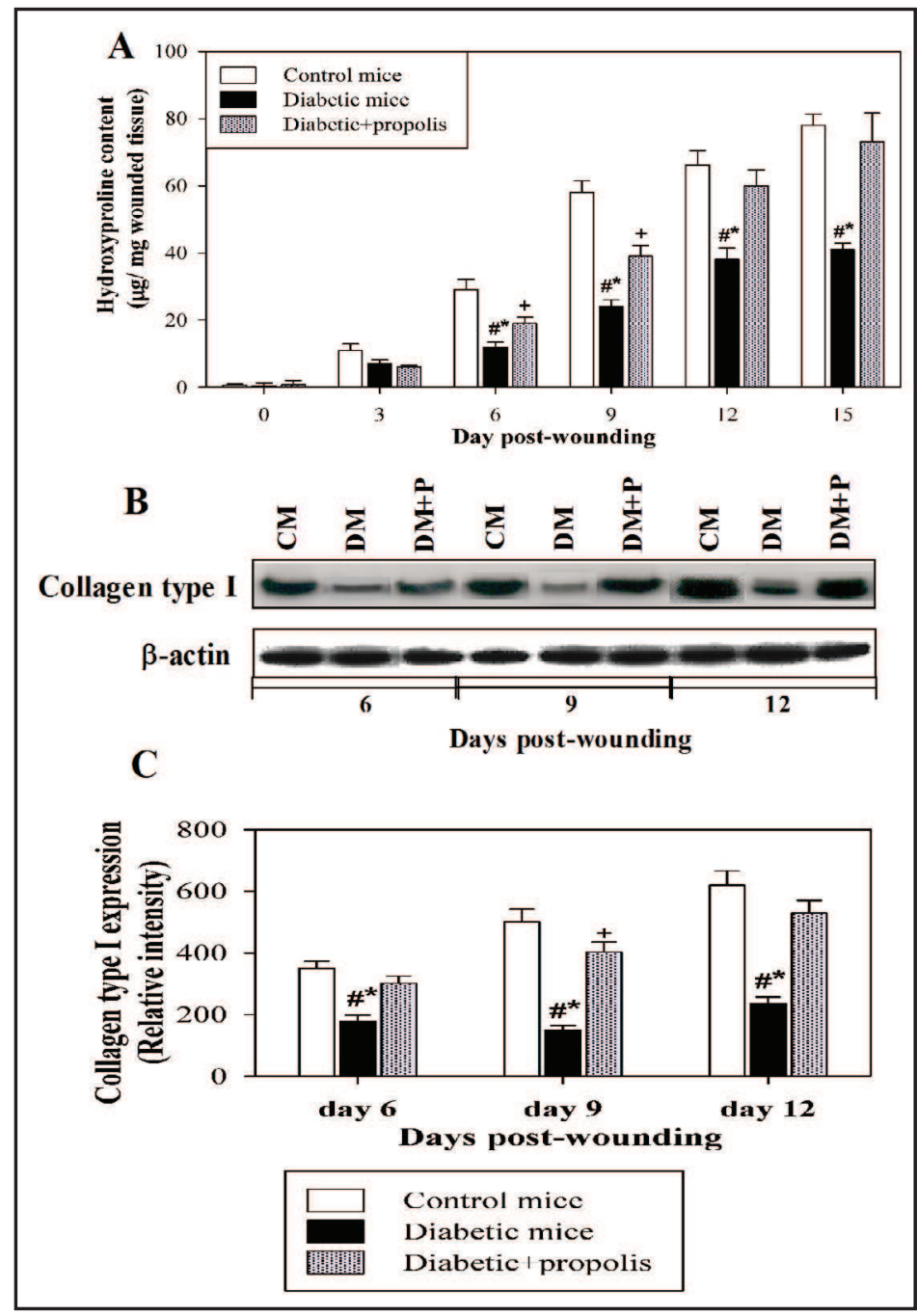

Interestingly, when diabetic mice were treated topically with the ethanolic soluble derivative of propolis, they exhibited a significant restoration of both normalized Smad2 and Smad3 phosphorylation. Similarly, accumulated data from five individual mice per group are shown for the normalized phosphorylation of Smad2 to total $\beta$-actin (Fig. 3E) and normalized phosphorylation of Smad3 to total $\beta$-actin (Fig. 3F).

Propolis enhances the production of collagen and accelerates diabetic wound healing

Increased collagen content in the extracellular matrix is a characteristic change observed during the proliferative phase of the wound healing process. As hydroxyproline is found almost exclusively in collagen, we used hydroxyproline content as an indicator of collagen type I levels at the wound sites. The accumulated data from 10 individual mice per group demonstrated that hydroxyproline content was significantly decreased in diabetic mice with decreased wound closure compared with control mice (Fig. 4A). Compared with control mice, there was less collagen accumulation at wound sites in diabetic mice, consistent with the delays in wound healing. However, diabetic mice that were treated topically with the ethanolic soluble derivative of propolis exhibited a significant restoration of hydroxyproline content compared with vehicle-treated diabetic mice. To confirm the alteration in the expression of collagen type I in the diabetic animals when treated topically with the ethanolic soluble derivative of propolis, Western blot analysis was assessed to monitor the expression of collagen type I at its protein level and one representative immunoblot showing one of the five experiments is shown (Fig. 4B) in control non-diabetic mouse (CM), vehicle- 


\section{Cellular Physiology Cell Physiol Biochem 2015;37:940-954

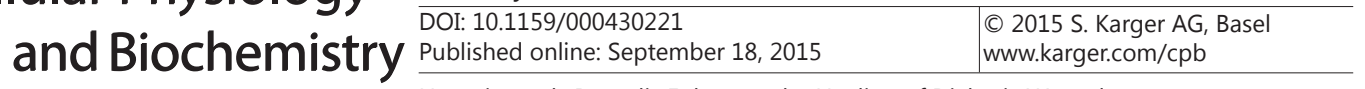 \\ Hozzein et al.: Propolis Enhances the Healing of Diabetic Wounds}

treated diabetic mouse (DM) and diabetic mouse treated with propolis (DM+P) in wounded tissues at 6, 9 and 12 days post-wounding. Our data demonstrated that the expression of collagen type I was markedly reduced in vehicle-treated diabetic mice, as the immunoblots showed very low intensity bands compared with control non-diabetic mice. By contrast, the propolis-treated diabetic mice displayed an obvious increase in the expression of collagen type I at 9 and 12 days post-injury, similar to the levels observed in the control nondiabetic mice. Accumulated data from five individual mice per group are shown (Fig. 4C) for the normalized values of collagen type I expression to the relative intensities of $\beta$-actin values. Our data revealed that vehicle-treated diabetic mice (closed black bars) exhibited a significant reduction in the collagen type I expression (from days 6 to 12 post-wounding compared with control (open bars) and propolis-treated diabetic mice (gray dotted bars). Interestingly, when diabetic mice were treated topically with the ethanolic soluble derivative of propolis, they exhibited a significant restoration of collagen type I expression.

\section{Discussion}

Natural antioxidants play central roles in enhancing the immune system through mechanisms dependent on the oxidative stress which, in turn, seems to play significant roles in many human diseases. In this context, we previously demonstrated the beneficial effects of thymoquinone in the treatment of multiple myeloma and improving the diabetic complications by restoring the $\mathrm{T}$ cell immune response in diabetic offspring [37-40]. Most interesting, we shown that natural antioxidants isolated from ants venoms were able to enhance the normal lymphocyte functions and exerts antitumor effects on the breast cancer cells [41]. Moreover, we provide clear evidences for the effects of camel whey protein for accelerating the healing process of diabetic wounds in experimental animal models $[34,42$, 43]. Propolis is a natural antioxidant product found in plant materials and is processed by worker bees.

The present study showed that the topical application of propolis to diabetic wounds in mice accelerated wound closure to a rate that was similar to that in non-diabetic control mice and significantly faster than that in untreated diabetic mice. These improvements were evident during the earliest stages post-incision and continued over the entire two-week study period, indicating that propolis application impacts all stages of the healing process. Our data are consistent with previous studies in humans and animals, as well as with older reports describing the use of propolis to treat ulcers [28-30]. Topical application of propolis had no effect on the glucose levels as shown in Table 1 suggesting that treatment of diabetic wounds with propolis accelerates the healing process by reversing the diabetic complication rather than lowering the glucose level.

The wound repair-enhancing effects of propolis are partly due to its anti-inflammatory properties. It is thought that prolonged inflammation impairs the healing process in diabetic patients, and it is recognized that elevated IL-1 $\beta$, IL- 6 , and TNF- $\alpha$ levels are found in diabetic wounds $[34,44]$. Therefore, it has been suggested that targeting inflammatory mediators could be an effective strategy for improving healing dynamics in diabetes. In the present study, we show that propolis application abrogated the inflammatory process associated with diabetic wounds and restored the expression of IL- $1 \beta$, IL- 6 and TNF- $\alpha$ to near wildtype levels. A direct inhibitory effect of propolis on cytokine production by immune cells has been documented [45], supporting the anti-inflammatory profile shown in the current study. Restoration of the proper expression levels of these cytokines is likely associated with inhibition of the inflammation feedback loop 45], as well as with decreased degradation of the ECM through the inhibition of MMP expression [46, 47]. Indeed, MMP9 levels were correlated with pro-inflammatory cytokine levels in this study, consistent with the hypothesis that propolis reduces proteolytic activity during cutaneous inflammation. It was previously 


\section{Cellular Physiology Cell Physiol Biochem 2015;37:940-954 \\ \begin{tabular}{l|l}
\hline and Bioch $10.1159 / 000430221$ & $\begin{array}{l}\text { D 2 2015 S. Karger AG, Basel } \\
\text { www.karger.com/cpb }\end{array}$ \\
\cline { 2 - 3 }
\end{tabular}}

reported that propolis and its extracts reduce MMP9 expression in diabetic wounds, particularly TNF-induced MMP9 [30]. In particular, fir honeydew flavonoids inhibited TNF$\alpha$-induced MMP9 expression in keratinocytes at both the gene and protein levels [48].

Propolis increased the levels of both collagen type 1 and its major constituent hydroxylproline in the wounds of diabetic mice. This finding was consistent with the accelerated healing observed in the treatment group compared with the diabetic PBS-treated group, which showed reduced expression of collagen type 1 and hydroxyproline. Similar healing profiles in the ECM (i.e., increased levels of collagen and its degradation products) were reported in rat excisional [28] and burn wounds [49] following propolis application. Additionally, enhanced healing and early stage replacement of collagen type III with collagen type I in burn wounds have been reported using propolis extract-coated collagen dressings [50]. Diminished collagen deposition is a mechanism of delayed wound healing, and propolis can restore the composition and quality of the ECM. These improvements may be due to reduced MMP9 levels, as described above, and indeed, the restoration of proper MMP9 levels using laser therapy improved ECM quality in diabetic mice [50]. However, in our study, increased collagen type I was observed at the level of gene expression, as well as at the protein level, as demonstrated by higher hydroxylproline values.

To further define the role of TGF- $\beta$ in enhancing wound healing following propolis application, we characterized TGF- $\beta 1$ gene expression at mRNA and protein levels, as well as phosphorylation of the downstream Smad transcription factors. Downregulation of the Smad2/3 signaling pathway is correlated with decreased collagen type 1 transcription in fibroblast cell lines [51]. Additionally, multiple studies using a variety of pharmacological and physical agents have demonstrated the induction of collagen expression and synthesis in dermal fibroblasts in a TGF- $\beta$ /Smad-dependent manner [52-54]. Therefore, a means to positively target the TGF- $\beta$ pathway would certainly be useful for the treatment of diabetic wounds. Strikingly, propolis application to diabetic wounds resulted in the upregulation of TGF- $\beta$ gene expression and enhanced Smad2/3 phosphorylation compared with Vehicletreated diabetic wounds, and these effects were observed from the earliest stages, peaking around day 9 of the study. In addition to the transcriptional activation of collagen expression, the downregulation of both TNF- $\alpha$ and MMP9 in the cutaneous wounds of diabetic mice is consistent with increased TGF- $\beta /$ Smad signaling, given that the upregulation of TGF- $\beta$ / Smad is accompanied by the downregulation of TNF- $\alpha$ and MMP9 as well as decreased inflammation. Indeed, the promoters of both factors harbor TGF- $\beta /$ Smad response elements, and TGF- $\beta$ has been shown to downregulate TNF- $\alpha$-induced MMP9 expression in monocytes [55]. Other potential mechanisms through which propolis application could promote wound healing via TGF- $\beta /$ Smad upregulation are the stimulation of keratinocyte migration and increased integrin expression [56], which will require further investigation.

It has been shown that HoxD3, a homeobox transcription factor that promotes angiogenesis and collagen synthesis, is up-regulated during normal wound repair whereas its expression is diminished in impaired healing wounds of the genetically diabetic $(\mathrm{db} / \mathrm{db})$ mouse as compared to wild-type mice with normal healing wounds [57]. In this context, it was concluded that decreased expression of HoxD3 was due to marked reduction in the expression of cytokines and growth factors including TGF- $\beta$, which are all reduced in diabetic models. [57]. Therefore, it is possible that treatment of diabetic wounds with propolis restored TGF- $\beta$ expression and signaling-mediating HoxD3 and Smad and subsequently collagen expression.

It has been established that TGF- $\beta$ induced proliferation of keratinocytes and fibroblasts, led to new formation of capillaries in the granulation tissue and modulated extracellular matrix deposition and reconstitution of the injured area. Additionally, topical application of growth factors was successful to accelerate healing of full thickness wound in normal mice and normalizes a delayed healing response of diabetic rats. Miyzono and Heldin reported 


\section{Cellular Physiology Cell Physiol Biochem 2015;37:940-954 \begin{tabular}{l|l} 
DOI: 10.1159/000430221 & () 2015 S. Karger AG, Basel
\end{tabular} and Biochemistry Published online: September 18, 2015 www.karger.com/cpb \\ Hozzein et al.: Propolis Enhances the Healing of Diabetic Wounds}

that TGF- $\beta$ is a family of multifunctional $25 \mathrm{KD}$ a protein (TGF-beta $1,2,3$ ) which stimulates collagen and fibronectin formation in variety of fibroblast cell lines [58]. Moreover, TGF-beta is known to regulate the differentiation of cells, induce chemotaxis of inflammatory cells and induce the accumulation of extra cellular matrix protein [59]. Spom et al. stated that TGF- $\beta$ is a human DNA-derived polypeptide growth factor that induces normal soft tissue repair mechanism and reverses deficient repair rates. This growth factor is released by platelets, monocytes/macrophages, endothelial cells and fibroblasts, cells that are essential to the repair process [60]. In this work by Spom et al. they found that TGF- $\beta$ played a central role in wound healing. It influenced the inflammatory response, angiogenesis, granulation tissue formation, reepithelization, extracellular matrix deposition and remodeling. Therefore, it is possible the effects of propolis in accelerating healing process of diabetic wounds was due to its direct effect on the expression of TGF- $\beta$ and it downstream signaling. The present study indicates that the topical application of propolis enhances the wound repair process in the context of diabetes by promoting TGF- $\beta /$ Smad signaling, leading to increased expression and deposition of collagen type I, reduced MMP expression, and decreased inflammation.

\section{Abbreviations}

Diabetes mellitus (DM); Extracellular matrix (ECM); Interleukin (IL); Matrix metalloproteinase (MMP); Streptozotocin (STZ); Transforming growth factor-beta (TGF- $\beta$ ); Tumor necrosis factor-alpha (TNF- $\alpha$ ).

\section{Acknowledgments}

This Project was funded by the National Plan for Science, Technology and Innovation (MAARIFAH), King Abdulaziz City for Science and Technology, Kingdom of Saudi Arabia, Award number (12-BI02609-02).

\section{Disclosure Statement}

The author declare no conflicts of interest, state that the manuscript has not been published or submitted elsewhere, state that the work complies with the Ethical Policies of the Journal and state that the work has been conducted under internationally accepted ethical standards after relevant ethical review.

\section{References}

1 Gurtner GC, Werner S, Barrandon Y, Longaker MT: Wound repair and regeneration. Nature 2008;453:314321.

2 Barrientos S, Stojadinovic O, Golinko MS, Brem H, Tomic-Canic M: Growth factors and cytokines in wound healing. Wound Repair Regen 2008;16:585-601.

3 Falanga V: Wound healing and its impairment in the diabetic foot. Lancet 2005;366:1736-1743.

4 Bruhn-Olszewska B, Korzon-Burakowska A, Gabig-Ciminska M, Olszewski P, Wegrzyn A, JakobkiewiczBanecka J: Molecular factors involved in the development of diabetic foot syndrome. Acta Biochim Pol 2012;59:507-513.

5 Dinh T, Tecilazich F, Kafanas A, Doupis J, Gnardellis C, Leal E, Tellechea A, Pradhan L, Lyons TE, Giurini JM, Veves A: Mechanisms involved in the development and healing of diabetic foot ulceration. Diabetes 2012;61:2937-2947.

6 Park JE, Barbul A: Understanding the role of immune regulation in wound healing. Am J Surg 2004;187:11S-16S.

7 Werner S, Grose R: Regulation of wound healing by growth factors and cytokines. Physiol Rev 2003;83:835870. 


\section{Cellular Physiology Cell Physiol Biochem 2015;37:940-954 \begin{tabular}{c|l}
\hline DOI: 10.1159/000430221 & (c) 2015 S. Karger AG, Basel
\end{tabular} and Biochemistry Published online: September 18, $2015 \quad$ www.karger.com/cpb}

8 Siqueira MF, Li J, Chehab L, Desta T, Chino T, Krothpali N, Behl Y, Alikhani M, Yang J, Braasch C, Graves DT: Impaired wound healing in mouse models of diabetes is mediated by tnf-alpha dysregulation and associated with enhanced activation of forkhead box o1 (foxo1). Diabetologia 2010;53:378-388.

9 Barui A, Banerjee P, Das RK, Basu SK, Dhara S, Chatterjee J: Immunohistochemical evaluation of p63, e-cadherin, collagen i and iii expression in lower limb wound healing under honey. Evid Based Complement Alternat Med 2011;2011:239864.

10 Martins VL, Caley M, O'Toole EA: Matrix metalloproteinases and epidermal wound repair. Cell Tissue Res 2013;351:255-268.

11 Badr G: Camel whey protein enhances diabetic wound healing in a streptozotocin-induced diabetic mouse model: The critical role of beta-defensin-1, -2 and -3. Lipids Health Dis 2013;12:46.

12 Black E, Vibe-Petersen J, Jorgensen LN, Madsen SM, Agren MS, Holstein PE, Perrild H, Gottrup F: Decrease of collagen deposition in wound repair in type 1 diabetes independent of glycemic control. Arch Surg 2003;138:34-40.

13 Bermudez DM, Herdrich BJ, Xu J, Lind R, Beason DP, Mitchell ME, Soslowsky LJ, Liechty KW: Impaired biomechanical properties of diabetic skin implications in pathogenesis of diabetic wound complications. Am J Pathol 2011;178:2215-2223.

14 Yang C, Zhu P, Yan L, Chen L, Meng R, Lao G: Dynamic changes in matrix metalloproteinase 9 and tissue inhibitor of metalloproteinase 1 levels during wound healing in diabetic rats. J Am Podiatr Med Assoc 2009;99:489-496.

15 Ladwig GP, Robson MC, Liu R, Kuhn MA, Muir DF, Schultz GS: Ratios of activated matrix metalloproteinase-9 to tissue inhibitor of matrix metalloproteinase- 1 in wound fluids are inversely correlated with healing of pressure ulcers. Wound Repair Regen 2002;10:26-37.

16 Massague J, Gomis RR: The logic of tgfbeta signaling. FEBS Lett 2006;580:2811-2820.

17 Hotz B, Visekruna A, Buhr HJ, Hotz HG: Beyond epithelial to mesenchymal transition: A novel role for the transcription factor snail in inflammation and wound healing. J Gastrointest Surg 2010;14:388-397.

18 Diegelmann RF, Evans MC: Wound healing: An overview of acute, fibrotic and delayed healing. Front Biosci 2004;9:283-289.

19 Wang X, Qian Y, Jin R, Wo Y, Chen J, Wang C, Wang D: Effects of trap-1-like protein (tlp) gene on collagen synthesis induced by tgf-beta/smad signaling in human dermal fibroblasts. PLoS One 2013;8:e55899.

20 Tredget EB, Demare J, Chandran G, Tredget EE, Yang L, Ghahary A: Transforming growth factor-beta and its effect on reepithelialization of partial-thickness ear wounds in transgenic mice. Wound Repair Regen 2005;13:61-67.

21 Liu Y, Min D, Bolton T, Nube V, Twigg SM, Yue DK, McLennan SV: Increased matrix metalloproteinase-9 predicts poor wound healing in diabetic foot ulcers. Diabetes Care 2009;32:117-119.

22 Al-Mulla F, Leibovich SJ, Francis IM, Bitar MS: Impaired tgf-beta signaling and a defect in resolution of inflammation contribute to delayed wound healing in a female rat model of type 2 diabetes. Mol Biosyst 2011;7:3006-3020.

23 Wagh VD: Propolis: A wonder bees product and its pharmacological potentials. Adv Pharmacol Sci 2013;2013:308249.

24 Chan GC, Cheung KW, Sze DM: The immunomodulatory and anticancer properties of propolis. Clin Rev Allergy Immunol 2013;44:262-273.

25 Boufadi YM, Soubhye J, Riazi A, Rousseau A, Vanhaeverbeek M, Neve J, Boudjeltia KZ, Van Antwerpen P: Characterization and antioxidant properties of six algerian propolis extracts: Ethyl acetate extracts inhibit myeloperoxidase activity. Int J Mol Sci 2014;15:2327-2345.

26 Falcao SI, Vale N, Cos P, Gomes P, Freire C, Maes L, Vilas-Boas M: In vitro evaluation of portuguese propolis and floral sources for antiprotozoal, antibacterial and antifungal activity. Phytother Res 2014;28:437-443.

27 McLennan SV, Bonner J, Milne S, Lo L, Charlton A, Kurup S, Jia J, Yue DK, Twigg SM: The anti-inflammatory agent propolis improves wound healing in a rodent model of experimental diabetes. Wound Repair Regen 2008;16:706-713.

28 Iyyam Pillai S, Palsamy P, Subramanian S, Kandaswamy M: Wound healing properties of indian propolis studied on excision wound-induced rats. Pharm Biol 2010;48:1198-1206.

29 Henshaw FR, Bolton T, Nube V, Hood A, Veldhoen D, Pfrunder L, McKew GL, Macleod C, McLennan SV, Twigg SM: Topical application of the bee hive protectant propolis is well tolerated and improves human diabetic foot ulcer healing in a prospective feasibility study. J Diabetes Complications 2014;28:850-857. 


\section{Cellular Physiology Cell Physiol Biochem 2015;37:940-954 \begin{tabular}{l|l}
\hline DOI: 10.1159/000430221 & (c) 2015 S. Karger AG, Basel
\end{tabular} \begin{tabular}{l|l} 
and Biochemistry Published online: September 18, 2015 & www.karger.com/cpb
\end{tabular}}

30 Lotfy M, Badra G, Burham W, Alenzi FQ: Combined use of honey, bee propolis and myrrh in healing a deep, infected wound in a patient with diabetes mellitus. Br J Biomed Sci 2006;63:171-173.

31 Mirza RE, Fang MM, Weinheimer-Haus EM, Ennis WJ, Koh TJ: Sustained inflammasome activity in macrophages impairs wound healing in type 2 diabetic humans and mice. Diabetes 2014;63:1103-1114.

32 Jerza G, Elnakady YA, Brauna A, Jackela K, Sassec F, Al Ghamdi AA, Omard OM, Winterhalter P: Preparative mass-spectrometry profiling of bioactive metabolites in Saudi-Arabian propolis fractionated by high-speed countercurrent chromatography and off-line atmospheric pressure chemical ionization mass-spectrometry injection. J Chromatogr A 2014;13:17-29.

33 Batista LL, Campesatto EA, Assis ML, Barbosa AP, Grillo LA, Dornelas CB: Comparative study of topical green and red propolis in the repair of wounds induced in rats. Rev Col Bras Cir 2012;39:515-520.

34 Badr G. Supplementation with undenatured whey protein during diabetes mellitus improves the healing and closure of diabetic wounds through the rescue of functional long-lived wound macrophages. Cell Physiol Biochem 2012;29:571-582.

35 Garraud O, Borhis G, Badr G, Degrelle S, Pozzetto B, Cognasse F, Richard Y: Revisiting the B-cell compartment in mouse and humans: more than one B-cell subset exists in the marginal zone and beyond. BMC Immunol 2012;13:63.

36 Ishida Y, Kondo T, Takayasu T, Iwakura Y, Mukaida N: The essential involvement of cross-talk between IFNgamma and TGF-beta in the skin wound-healing process. J Immunol 2004;172:1848-1855.

37 Badr G, Lefevre EA, Mohany M: Thymoquinone inhibits the CXCL12-induced chemotaxis of multiple myeloma cells and increases their susceptibility to Fas-mediated apoptosis. PLoS One 2011;6:e23741.

38 Badr G, Alwasel S, Ebaid H, Mohany M and Alhazza I: Perinatal Supplementation With Thymoquinone Improves Diabetic Complications and T Cell Immune Responses in Rat Offspring. Cell Immunol 2011; 267:133-140.

39 Badr G, Mohany M and Abou-Tarboush F: Thymoquinone decreases F-actin polymerization and proliferation of human multiple myeloma cells through suppression of STAT3 phosphorylation and Bcl2/ Bcl-XL expression. Lipids Health Dis 2011;10:236.

40 Mohany M, El-Feki M, Refaat I, Garraud O, Badr G: Thymoquinone ameliorates the immunological and histological changes induced by exposure to imidacloprid insecticide. J Toxicol Sci 2012;37:1-11.

41 Badr G, Garraud O, Daghestani M, Al-Khalifa M and Richard Y: Human breast carcinoma cells are induced to apoptosis by samsum ant venom through an IGF-1-dependant pathway, PI3K/AKT and ERK signaling. Cell Immunol 2012;273:10-16.

42 Badr G, Mohany M, Badr BM, Mahmoud MH, Rabah DM, Garraud O: Treatment of diabetic mice with undenatured whey protein enhances healing of diabetic wounds through the reduction of proinflammatory stimuli and modulation of the expression of MIP-1 $\alpha$, MIP-2, CX3CL1 and TGF- $\beta$. BMC Immunol 2012;13:32.

43 Badr G, Ebaid H, Mohany M and Abu el-saad A: Modulation of immune cell proliferation and chemotaxis towards CC chemokine ligand (CCL)-21 and CXC chemokine ligand (CXCL)-12 in un-denatured whey protein-treated mice. J Nutr Biochem 2012; 23:1640-1646.

44 Bufalo MC, Bordon-Graciani AP, Conti BJ, de Assis Golim M, Sforcin JM: The immunomodulatory effect of propolis on receptors expression, cytokine production and fungicidal activity of human monocytes. J Pharm Pharmacol 2014;66:1497-1504.

45 Agren MS, Schnabel R, Christensen LH, Mirastschijski U: Tumor necrosis factor-alpha-accelerated degradation of type i collagen in human skin is associated with elevated matrix metalloproteinase (mmp)1 and mmp-3 ex vivo. Eur J Cell Biol 2015;94:12-21.

46 Frankova J, Diamantova D, Vrbkova J, Ulrichova J: Influence of hydrogencalcium salts of oxidized cellulose on mmp-2, mmp-9 and tnf-alpha production and wound healing in non-healing wounds. Acta Dermatovenerol Croat 2013;21:219-223.

47 Majtan J, Bohova J, Garcia-Villalba R, Tomas-Barberan FA, Madakova Z, Majtan T, Majtan V, Klaudiny J: Fir honeydew honey flavonoids inhibit tnf-alpha-induced mmp-9 expression in human keratinocytes: A new action of honey in wound healing. Arch Dermatol Res 2013;305:619-627.

48 Olczyk P, Wisowski G, Komosinska-Vassev K, Stojko J, Klimek K, Olczyk M, Kozma EM: Propolis modifies collagen types i and iii accumulation in the matrix of burnt tissue. Evid Based Complement Alternat Med 2013;2013:423809. 


\section{Cellular Physiology Cell Physiol Biochem 2015;37:940-954 \begin{tabular}{c|c}
\hline DOI: 10.1159/000430221 & (C) 2015 S. Karger AG, Basel
\end{tabular} and Biochemistry Published online: September 18, $2015 \quad$ www.karger.com/cpb}

49 de Almeida EB, Cordeiro Cardoso J, Karla de Lima A, de Oliveira NL, de Pontes-Filho NT, Oliveira Lima S, Leal Souza IC, de Albuquerque-Junior RL: The incorporation of brazilian propolis into collagen-based dressing films improves dermal burn healing. J Ethnopharmacol 2013;147:419-425.

50 Aparecida Da Silva A, Leal-Junior EC, Alves AC, Rambo CS, Dos Santos SA, Vieira RP, De Carvalho Pde T: Wound-healing effects of low-level laser therapy in diabetic rats involve the modulation of mmp-2 and mmp-9 and the redistribution of collagen types I and III. J Cosmet Laser Ther 2013;15:210-216.

51 Cho JW, Il KJ, Lee KS: Downregulation of type I collagen expression in silibinin-treated human skin fibroblasts by blocking the activation of smad2/3-dependent signaling pathways: Potential therapeutic use in the chemoprevention of keloids. Int J Mol Med 2013;31:1148-1152.

52 Zhao D, Shi Y, Dang Y, Zhai Y, Ye X: Daidzein stimulates collagen synthesis by activating the tgf-beta/smad signal pathway. Australas J Dermatol 2015;56:e7-e14.

53 Wu CS, Wu PH, Fang AH, Lan CC: Fk506 inhibits the enhancing effects of transforming growth factor (tgf)-beta1 on collagen expression and tgf-beta/smad signalling in keloid fibroblasts: Implication for new therapeutic approach. Br J Dermatol 2012;167:532-541.

54 Dang Y, Liu B, Liu L, Ye X, Bi X, Zhang Y, Gu J: The 800-nm diode laser irradiation induces skin collagen synthesis by stimulating tgf-beta/smad signaling pathway. Lasers Med Sci 2011;26:837-843.

55 Vaday GG, Schor H, Rahat MA, Lahat N, Lider O: Transforming growth factor-beta suppresses tumor necrosis factor alpha-induced matrix metalloproteinase-9 expression in monocytes. J Leukoc Biol 2001;69:613-621.

56 Ponugoti B, Xu F, Zhang C, Tian C, Pacios S, Graves DT: Foxo1 promotes wound healing through the upregulation of TGF-beta1 and prevention of oxidative stress. J Cell Biol 2013;203:327-343.

57 Hansen SL, Myers CA, Charboneau A, Young DM, Boudreau N: HoxD3 accelerates wound healing in diabetic mice. Am J Pathol 2003;163:2421-2431.

58 Miyzono K, Heldin CH: Structure, function and possible clinical application of TGF-beta 1. J Dermatol 1992;19:644-647.

59 Papadimitriou A, Peixoto EB, Silva KC, Lopes de Faria JM, Lopes de Faria JB. Inactivation of AMPK mediates high phosphate-induced extracellular matrix accumulation via NOX4/TGFß-1 signaling in human mesangial cells. Cell Physiol Biochem 2014;34:1260-1272.

60 Spom MB, Roberts AB, Wakefield NM, de Crombrugghe B: Some recent advances in the chemistry and biology of TGF-beta. J Cell Biol 1987;105:1039-1045. 